\title{
Vegetative Characteristics of Sage-grouse Nesting and Brood Rearing Sites
}

\author{
Vanessa Lane \\ Department of Animal and Range Sciences \\ PO Box 172900, Bozeman, MT 59717-2900, United States
}

Tel: 1-229-391-4811Ｅ-mail: vlane@abac.edu

Jenny Sika

Montana Fish, Wildlife and Parks, Region 3

PO Box 200701, Helena, MT 59620, United States

Tel: 1-406-495-3268Ｅ-mail: jsika@mt.gov

\begin{abstract}
Carl Wambolt
Department of Animal and Range Sciences

PO Box 172900, Bozeman, MT 59717-2900, United States

Tel: 1-406-994-5580Ｅ-mail: cwambolt@montana.edu
\end{abstract}

Michael R. Frisina

Department of Animal and Range Sciences

PO Box 172900, Bozeman, MT 59717-2900, United States

Tel: 1-406-994-5580 E-mail: mfrisina@bresnan.net

Bok Sowell (Corresponding author)

Department of Animal and Range Sciences

PO Box 172900, Bozeman, MT 59717-2900, United States

Tel: 1-405-994-5558_E-mail: bok@montana.edu 
Received: March 15, 2017 Accepted: April 12, 2017

doi:10.5296/emsd.v6i1.11090

URL: https://doi.org/10.5296/emsd.v6i1.11090

\begin{abstract}
Vegetative characteristics of 146 greater sage-grouse (Centrocercus urophasianus) nest sites and 48 brood rearing sites were compared with paired random sites to determine if hens were selecting sites with certain vegetative attributes at three study areas in central Montana in 2003 and 2004. Ninety-seven percent of all nest locations and 92\% of all brood rearing locations were in Wyoming big sagebrush (Artemisia tridentata Nutt. ssp. wyomingensis Beetle \& Young) plants. Therefore, only attributes of Wyoming big sagebrush plants were analyzed. Shrub characteristics such as percent cover, density (shrubs $/ \mathrm{m}^{2}$ ), average shrub height $(\mathrm{cm})$, nest shrub height $(\mathrm{cm})$ and nest shrub production $(\mathrm{g} / \mathrm{shrub})$ were recorded. Herbaceous measurements such as forb cover (\%), grass cover $(\%)$, total cover $(\%)$ and grass height $(\mathrm{cm})$ were recorded. Sage-grouse hen nest sites had greater $(\mathrm{P} \leq 0.05)$ average shrub height (36 vs $31 \mathrm{~cm})$ and more $(\mathrm{P} \leq 0.05)$ nest shrub production $(55 \mathrm{vs} 48 \mathrm{~g} / \mathrm{shrub})$ than random sites. There were no differences in sagebrush cover density or nest shrub height or any herbaceous characteristics between nest and random sites. Fifty percent of all nests were successful. Successful nest sites were not different from unsuccessful nest sites in any shrub or herbaceous component. There were no differences in shrub or herbaceous measurements between yearling and adult nest sites. Shrub and herbaceous characteristics of brood sites did not differ from random sites. Average shrub height was greater $(\mathrm{P} \leq 0.05)$ for adult brood rearing sites compared to yearling sites $(35$ vs $31 \mathrm{~cm})$. Brood site shrub cover was less $(\mathrm{P} \leq$ 0.05 ) than nest shrub cover (14 vs $21 \%$ ). Our results suggest that even though nesting sage-grouse hens selected for taller and more productive Wyoming big sagebrush plants, these attributes did not improve nesting success. Grazing guidelines suggested to increase herbaceous vegetation may not improve nesting or brood rearing success. Although brood rearing vegetative characteristics were lower $(\mathrm{P} \leq 0.05)$ in sagebrush cover and production than nesting sites, managers should not reduce Wyoming big sagebrush cover or production to emphasize one stage of sage-grouse production since this plant is vital for all life phases.
\end{abstract}

Keywords: Wyoming big sagebrush, Sagebrush cover, Herbaceous cover, Grass height

\title{
1. Introduction
}

Declining numbers of greater sage-grouse (Centrocercus urophasianus) have concerned biologists for over 80 years (Connelly, Schroeder, Sands and Braun 2000). Sagebrush (Artemisia L.) habitat loss, fragmentation, and degradation are the primary factors attributed to sage-grouse declines (Connelly and Braun 1997; Schroeder et al. 2000; Wambolt et al. 2002; Crawford et al. 2004). Sage-grouse require sagebrush habitat for nesting and brood rearing (Klebenow 1969; Rowland 2004; Wallestad 1971; Drut, Pyle and Crawford 1994).

Connelly, Schroeder, Sands and Braun (2000) suggested that nesting sage-grouse need 15-25\% sagebrush cover, sagebrush heights of $30-80 \mathrm{~cm}, \geq 15 \%$ herbaceous cover, and 
grass heights $>18 \mathrm{~cm}$. While this may be the case in other areas within the range of sage-grouse, few studies were available to support or refute these guidelines in Montana. Sagebrush and herbaceous cover for nests in Petroleum County, Montana were similar (19\% and $51 \%$ ) (Pyrah 1972; Wallestad and Pyrah 1974) to the guidelines proposed by Connelly, Schroeder, Sands and Braun (2000). Shrub cover for brood locations in Beaverhead County, Montana also matched the shrub cover guideline (19\% vs. 10-25\%, respectively) (Martin 1965) for broods proposed by Connelly, Schroeder, Sands and Braun (2000). While these habitat values fall within the suggested guidelines, these two areas may not adequately represent sage-grouse habitat across Montana. Shrub and herbaceous data were needed from other areas of Montana to determine if nesting and brood-rearing habitat was similar.

Hagen, Connelly and Schroeder (2007) conducted an extensive meta analysis of vegetation characteristics from 32 studies of nesting and brood-rearing habitats and found that sagebrush cover and grass height was greater at nest sites than random sites. They further concluded that vegetation at brood areas had less sagebrush cover, taller grasses, and greater forb and grass cover than random locations.

Doherty et al. (2014) examined the role of grass height to explain variation in sage-grouse nest survival. Using some of the same study areas that we used, they concluded that grass height was highly predictive as a management tool to increase nesting success.

The primary objectives of this study were to compare shrub and herbaceous characteristics between 1) nest and random sites near Roundup in central Montana, Decker in south-central Montana and south of Malta in north-central Montana; and 2) brood and random sites near Roundup and Decker to determine if hens selected for specific vegetation characteristics.

Secondary objectives were to compare shrub and herbaceous parameters between 1) successful and failed nests, 2) yearling and adult hen nests, 3) yearling and adult hen brood sites, and 4) nest and brood sites.

\section{Methods}

\subsection{Study Area Descriptions}

\subsubsection{Roundup Study Area}

Precipitation averages $31 \mathrm{~cm}$ annually, with peak rainfall occurring mostly from May and June (National Oceanic and Atmospheric Administration (NOAA) 2004). Precipitation in 2003 was approximately normal. In 2004, this area received only $6 \mathrm{~cm}$ of precipitation between January and July, which was $3 \mathrm{~cm}$ below average. Soil taxonomic units which characterize this area include Cabba, Cabbart, and Yamacall (United States Department of Agriculture (USDA) 2003). Elevation range is 826-1495 m.

This area was a mixture of farmland and grazed native prairie, and most land was privately owned. Wyoming big sagebrush (Artemisia tridentata Nutt. ssp. wyomingensis Beetle \& Young) was the dominant shrub although silver sagebrush (Artemisia cana Pursh) and greasewood (Sarcobatus vermiculatus (Hook.) Torr.) were also present. Western wheatgrass (Pascopyron smithii (Rydb.) A. Löve), Sandberg bluegrass (Poa secunda J.Presl), and blue 
grama (Bouteloua gracilis (Willd. ex Kunth) Lag. ex Griffiths) were the dominant grasses, while green needlegrass (Nassella viridula (Trin.) Barkworth), needle-and-thread (Hesperostipa comata (Trin. \& Rupr.) Barkworth), and threadleaf sedge (Carex filifolia Nutt.) were also common. Scarlet globemallow (Sphaeralcea coccinea (Nutt.) Rydb.), wild onion (Allium sp. L.), Hood's phlox (Phlox hoodii Richards), and American vetch (Vicia americana Muhl. ex Willd.) were the most abundant forbs. Seeded areas had crested wheatgrass (Agropyron cristatum (L.) Gaertn.), alfalfa (Medicago sativa L.), and wheat (Triticum aestivum L.). Vegetation was similar in Golden Valley and Musselshell Counties (Appendix A); therefore vegetation data for nest and brood sites from these 2 sites were combined to characterize nesting and brood-rearing habitat.

\subsubsection{Decker Study Area}

Annual precipitation averaged $31 \mathrm{~cm}$ with peak precipitation occurring from April to June (NOAA 2003a). January to May precipitation was $1 \mathrm{~cm}$ above average, while June and July were $1 \mathrm{~cm}$ below average in 2003. Soil taxonomic units which characterize this area include Midway, Pierre, and Thedalun (USDA Natural Resource Conservation Service (NRCS) 2004). Elevation range is $762-1314 \mathrm{~m}$.

Wyoming big sagebrush was the dominant shrub, although silver sagebrush, skunkbrush sumac (Rhus trilobata Nutt.), common juniper (Juniperus communis L.) and rubber rabbitbrush (Ericameria nauseosus (Pallas ex Pursh) Nesom \& Baird) were also present. Sandberg bluegrass, western wheatgrass, and Japanese brome (Bromus japonicus Thunb. ex Murr.) were the dominant grasses, although green needlegrass, prairie junegrass (Koeleria macrantha (Ledeb.) J.A. Schultes), and bluebunch wheatgrass (Psuedoroegneria spicata (Pursh) A. Löve) were also common. Desert alyssum (Alyssum desertorum Stapf), Hood's phlox, scarlet globemallow, American vetch, dandelion (Taraxacum officinale G.H. Weber ex Wiggers), and western yarrow (Achillea millefolium L.) were the most common forbs.

\subsubsection{Malta Study Area}

Annual precipitation averaged $31 \mathrm{~cm}$ with peak precipitation between April and July (Western Regional Climate Center (WRCC 2004)). May, June, and July were 0.02, 0.53, and $1.54 \mathrm{~cm}$ below average in 2003 which could have reduced forb and grass production (NOAA 2003b). Soil taxonomic units that characterized this area included Absher, Elloam, and Thoeny (USDA 1981). Elevation range is 600-1060 m.

Approximately $60 \%$ of this area was publicly owned by the U.S. Bureau of Land Management (BLM), the U.S. Fish and Wildlife Service (FWS), and the state of Montana (Moynahan 2004). Sage-grouse have relatively large, stable populations in this area (Montana Sage-Grouse Work Group (MSGWG) 2002).

Wyoming big sagebrush was the dominant shrub although silver sagebrush, greasewood, and rubber rabbitbrush were also present. Western wheatgrass, and blue grama were the dominant grasses, while Sandberg bluegrass, needle-and-thread, and threadleaf sedge were also common. American vetch, scarlet globemallow, and dandelion were the most common forbs. Fringed sagewort (Artemisia frigida Willd.), lesser spikemoss (Selaginella densa Rydb.), and 
prickly pear (Opuntia spp. P. Mill) were also common.

\subsection{Sampling Methods}

\subsubsection{Bird Capture}

In the Roundup Study Area, hens from 9 leks in Musselshell and Golden Valley counties near Roundup in central Montana were trapped and fitted with radio collars by Montana State University in the spring of 2004. Sage-grouse in this area were nonmigratory.

Within the Decker Study Area, hens were captured, fitted with radio collars, and tracked to nests in Bighorn County in south-central Montana in the spring and summer of 2003 by the University of Montana. Study sites were mostly private ranchland with some Bureau of Land Management (BLM) and state land. Sage-grouse in this area are nonmigratory.

In the Malta Study Area, hens were captured and tracked approximately $80 \mathrm{~km}$ south of Malta in southern Phillips County in north-central Montana during the spring and summer of 2003 by the University of Montana.

\subsubsection{Nest Sites}

Sagebrush canopy cover, density, and height, nest shrub height, nest shrub productivity, forb, grass, herbaceous, and residual cover, grass height, and residual height were measured. Sagebrush canopy cover was measured using the line-intercept method (Canfield 1941; Klebenow 1969; Gregg 1991; Aldridge and Brigham 2002), and was considered more precise than other methods (Connelly, Reese and Schroeder 2003). Line-intercepts were measured on 2 perpendicular $30 \mathrm{~m} \mathrm{~N}-\mathrm{S}$ and $\mathrm{E}-\mathrm{W}$ transects, with the nest located at the center $(15 \mathrm{~m})$ of each line. True north was used to orient the lines at each sampling location. Gaps in sagebrush canopy that were greater than $3 \mathrm{~cm}$ were recorded, and the amount of live versus dead canopy cover was noted (Wambolt, Frisina, Knapp and Frisina 2006). Dead sagebrush was never more than $3 \%$ cover of the total line intercept, and therefore it was combined with live cover and only total sagebrush cover was reported. The 2 transects were averaged for analysis at each nest site.

Two $30 \mathrm{~m}$ by $2 \mathrm{~m}$ belt transects were measured along each N-S, E-W line to measure sagebrush density (number of shrubs $/ \mathrm{m}^{2}$ ) around the nest site. Large plots such as belt transects were useful to measure density on large plants (Gurevitch, Scheiner and Fox 2002). The 2 belt transects for each site were averaged to obtain an estimate of sagebrush density per nest site. Belt transects were determined by holding a $1 \mathrm{~m}$ measuring stick and walking the length of the tape on both sides. All live and dead sagebrush with a crown diameter $\geq 15 \mathrm{~cm}$ were counted. Sagebrush with crown diameters $<15 \mathrm{~cm}$ were considered immature and were not large enough to provide cover for sage-grouse. Dead sagebrush density never provided more than 0.3 shrubs per $\mathrm{m}^{2}$, and was combined with live sagebrush density with only total sagebrush density recorded.

Average shrub height around the nest site was estimated by measuring the nearest shrub to the line-intercept at $3 \mathrm{~m}$ intervals within $15 \mathrm{~m}$ of the nest shrub for a total of 10 shrub height measurements per line. Height of the nest shrub was also measured. Nest shrub productivity 
was calculated by measuring the nest shrub's major axis, followed by a perpendicular minor axis, and $2-45^{\circ}$ crown width measurements, and is reported in grams of available winter forage (Wambolt, Creamer and Rossi, 1994). This parameter could not be calculated for Decker due to missing values, although nest shrub height is reported.

Herbaceous understory cover and composition were measured using 20 x $50 \mathrm{~cm}$ quadrats (Daubenmire 1959). Connelly, Reese and Schroeder (2003) considered these quadrats to be precise and repeatable. The same $\mathrm{N}-\mathrm{S}, \mathrm{E}-\mathrm{W}$ transects used for line-intercepts and belt transects were used for the herbaceous measurements. Quadrats were placed at 3, 6, 9, 12, and $15 \mathrm{~m}$ from nest shrub for a total of 20 at each nest site. Total herbaceous, forb, and grass cover were measured by this method. Vegetative height of living grass was also recorded at each quadrat. Residual grass cover and height were also measured at the Roundup study area, but not in Decker or Malta. There were no differences between Daubenmire plots at 3, 6, 9, 12 , and $15 \mathrm{~m}$ from the nest, therefore cover and height data from all quadrats were averaged for statistical analyses.

Nests were considered successful if shell membranes were detached from the shell (Wallestad 1975). This only required one egg to hatch. Hens with worn outermost primaries were considered adults (Wallestad 1975).

\subsubsection{Random Sites}

In the Roundup study area, random sites were paired with nest sites within the same vegetation type to test if sage-grouse hens were randomly selecting shrub or herbaceous characteristics for nesting. The paired random design examined sage-grouse nest selection on a relatively small scale, and was useful to detect within-stand habitat preferences of nesting sage-grouse.

Shrub and herbaceous characteristics of random sites were measured using the same methods used to measure nest sites. Random sites were measured on the same or next day as their paired nest sites. At each nest site a random compass direction and distance (between 30 and $1000 \mathrm{~m}$ ) were chosen using random number tables. The tallest sagebrush $\geq 35 \mathrm{~cm}$ nearest the end of the random distance was selected as the random nest shrub. If the habitat encountered at the random site was not sagebrush (i.e. road, uniform agricultural field, etc.), the closest sagebrush stand in the same direction was selected and, using the milliseconds indicator on a stopwatch, a random distance from 15 to $100 \mathrm{~m}$ was determined to locate sampling sites.

At the Decker and Malta study areas, random sites were selected by using Arcview ${ }^{\circledR}$ to select random coordinates within a $5 \mathrm{~km}$ radius of each lek, with the restriction that points had to be at least $1 \mathrm{~km}$ apart. Random sites were restricted to those in sagebrush-grassland habitat; random sites that fell in other habitats (e.g., riparian, conifer) were not used. Random sites were measured using the same methods as actual nest sites, but they were measured an average of 1 month later than nest sites at both study sites. Random nest shrub heights were not measured at Decker. 


\subsubsection{Brood Sites}

Hens with broods were tracked throughout the brood-rearing season. Shrub and herbaceous parameters at brood sites were measured using the same methods as nest sites. In Roundup, paired random sites were located for brood sites using the same methods described for paired random sites for nests. Broods were located at 1, 2, and 4 weeks after hatch with 1 site per brood measured at each week. In Decker, the same random sites that were compared to nest sites were also compared to brood sites. Broods in Decker were located 1-10, 11-20, 21-30, and 31-40 days after hatch. Brood sites were not measured in Malta.

\subsection{Statistical Analysis}

To test our primary objectives, measured parameters at nest and brood sites were compared with random sites to determine if nest and brood sites differed in any way from random sites. Individual nest or brood sites were the experimental unit. The parameters tested included shrub cover, density, and height; forb, grass, herbaceous, and residual cover; grass and residual height; nest shrub height; and nest shrub productivity. These variables were first tested for normality using the Shapiro-Wilk test. If $\mathrm{P} \leq 0.05$ with this test, the variable was considered to have a non-normal distribution and a nonparametric test was used. Wilcoxon signed ranks tests were used for variables with non-normal distributions. Only nests in the Wyoming big sagebrush habitat type had a sufficient sample size to be analyzed. Differences were considered significant at $\mathrm{P} \leq 0.05$. All data were analyzed using $S A S^{\circledR}$ version 9 .

The above vegetation parameters, except for nest shrub height and productivity, were tested between brood and random sites. Paired $t$-tests or Wilcoxon ranks sum tests were used to compare brood and random sites, while 2-independent sample t-tests or Wilcoxon-Mann-Whitney tests were used when needed.

The same vegetation parameters compared between nest and random sites were also compared between successful and failed nest sites, yearling and adult hen nest sites, and yearling and adult hen brood sites using 2-independent sample t-tests or Wilcoxon-Mann-Whitney tests.

Shrub canopy cover, density, and height were also compared between nest and brood sites to determine if nesting hens selected different habitat than hens with broods. Herbaceous parameters were not included because brood sites were measured later than nest sites. Shrub variables were compared using 2-independent sample t-tests or Wilcoxon-Mann-Whitney tests.

\section{Results and Discussion}

\subsection{Nest Sites}

A total of 146 nest sites and 146 random sites were measured. Ninety seven percent of all sage-grouse nested under Wyoming big sagebrush. Nest sites averaged 20\% sagebrush cover, 1.4 shrubs $/ \mathrm{m}^{2}, 36 \mathrm{~cm}$ average height, $57 \mathrm{~cm}$ shrub nest shrub height and $55 \mathrm{~g} / \mathrm{shrub}$ annual production (Table 1). Hens did not appear to select sites that were different from random sites except for selecting for greater than average nesting shrub height and nest shrub production 
$(\mathrm{P} \leq 0.05)$. Herbaceous characteristics did not differ between nest and random sites (Table 1).

Wakkinen (1990) found that only nest shrub characteristics at the nest site were different from dependent random sites within $200 \mathrm{~m}$ of the nest in Idaho, and actual nest shrubs were taller and provided more cover than random nest shrubs. Wakkinen (1990) also found that grass height was the only variable that differentiated nests from independent random sites within his study area. Therefore, at small scales within $1 \mathrm{~km}$ of a nest site, nest site selection appears to be driven by the selection of a nest shrub. At larger scales, sage-grouse select sagebrush stands with certain characteristics, but not all of these characteristics were similar between areas.

The amount of sagebrush cover has been recognized as important to nesting sage-grouse (Crawford et al. 2004, Hagen, Connelly and Schroeder 2007). At the Roundup, Decker, and Malta study areas, nest sites had 19-22\% sagebrush cover, which falls within the range of the 15-25\% guideline proposed by Connelly, Schroeder, Sands and Braun (2000). No single vegetation variable differed between nest and random sites between all study areas, indicating that no single habitat characteristic may differentiate nests from random sites across the state of Montana.

Connelly, Schroeder, Sands and Braun (2000) suggested that grass and forb cover should exceed $10 \%$ and $15 \%$, and that grass heights should be greater than $18 \mathrm{~cm}$. We did not find any differences for all herbaceous measurements between nest and random sites. Our forb cover values were lower than the forb cover guideline. This may have been influenced by a series of dry growing seasons. Lower grass height near Roundup and Malta was due to the abundance of blue grama, which typically does not reach $18 \mathrm{~cm}$.

Our study areas have some of the largest intact stands of sagebrush left in Montana (Moynahan 2004, MSGWG 2002). Sage-grouse populations in this area are stable and relatively large (MSGWG 2002). Nesting sage-grouse used areas with similar vegetation as random sites. Sagebrush cover and height within $15 \mathrm{~m}$ of the nest site met the guidelines suggested by Connelly, Schroeder, Sands and Braun (2000) but were at the lowest values of these guidelines. Grass height averaged between 15 and $18 \mathrm{~cm}$ for all 3 locations but did not meet the nesting habitat guideline suggested by Connelly, Schroeder, Sands and Braun (2000).

Hagen, Connelly and Schroeder (2007) suggested studies compare vegetation differences between successful and unsuccessful nest sites. Our study failed to detect any shrub or herbaceous characteristics differences between successful and unsuccessful nest sites (Table $1)$.

Doherty et al. (2014) also examined grass height influence on nest success in our area from 2003 to 2007. Using 529 nest sites and categorizing nests into two bins, probabilities $<0.45$ and $>0.55$ apparent success rate. They found that except for 2003, grass height successfully predicted the apparent nest success. Since our study was based on data taken mostly from 2003, which had an early wet spring and unusually tall grass heights, we did not detect any influence of grass height on nest success. Differences between the two studies were likely 


\section{Macrothink}

Environmental Management and Sustainable Development

ISSN 2164-7682 2017, Vol. 6, No. 1

due to environmental conditions and how the data was categorized.

Table 1. Comparisons of vegetation means at sage-grouse nest and random sites, successful and failed nests, and yearling and adult nests in Wyoming big sagebrush habitats in Montana in 2003-2004

\begin{tabular}{|c|c|c|c|c|c|c|c|c|c|c|}
\hline & & \multicolumn{5}{|c|}{ Sagebrush Characteristics } & \multicolumn{4}{|c|}{ Herbaceous Characteristics } \\
\hline & $\mathrm{N}$ & $\begin{array}{l}\text { total } \\
\text { cover }\end{array}$ & $\begin{array}{c}\text { total } \\
\text { density }\end{array}$ & $\begin{array}{l}\text { shrub } \\
\text { height }\end{array}$ & $\begin{array}{c}\text { nest shrub } \\
\text { height }\end{array}$ & $\begin{array}{c}\text { nest shrub } \\
\text { prod. }\end{array}$ & $\begin{array}{l}\text { forb } \\
\text { cover }\end{array}$ & $\begin{array}{l}\text { grass } \\
\text { cover }\end{array}$ & $\begin{array}{l}\text { total } \\
\text { cover }\end{array}$ & $\begin{array}{r}\text { grass } \\
\text { height }\end{array}$ \\
\hline & & $(\%)$ & $\left(\operatorname{shrubs} / \mathrm{m}^{2}\right)$ & \multicolumn{2}{|c|}{------(cm)------ } & (g) & \multicolumn{3}{|c|}{----------(\%)----------- } & $(\mathrm{cm})$ \\
\hline Nest Sites ${ }^{1}$ & 146 & 20 & 1.4 & $36^{\mathrm{a}}$ & 57 & $55^{\mathrm{a}}$ & 6 & 20 & 26 & 16 \\
\hline Random Sites & 146 & 17 & 1.1 & $31^{\mathrm{b}}$ & 54 & $48^{\mathrm{b}}$ & 6 & 20 & 27 & 15 \\
\hline Successful Nests ${ }^{2}$ & 51 & 21 & 1.4 & 40 & 61 & 57 & 7 & 18 & 25 & 18 \\
\hline Failed Nests & 50 & 21 & 1.3 & 39 & 62 & 57 & 8 & 19 & 27 & 17 \\
\hline Yearling Nests $^{2}$ & 33 & 19 & 1.4 & 39 & 62 & 54 & 6 & 18 & 25 & 16 \\
\hline Adult Nests & 67 & 21 & 1.4 & 40 & 61 & 56 & 8 & 19 & 27 & 18 \\
\hline
\end{tabular}

${ }^{1}$ Based on nests from Roundup, Decker and Malta, MT.

${ }^{2}$ Based on nests from Roundup and Decker, MT.

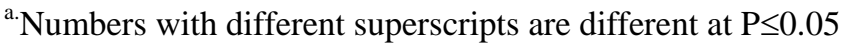

\subsection{Brood Sites}

Forty four of 48 (92\%) brood locations were found in Wyoming big sagebrush vegetation types. They averaged $14 \%$ shrub cover, $1.2 \mathrm{shrubs} / \mathrm{m}^{2}$ and an average shrub height of $34 \mathrm{~cm}$ (Table 2). Herbaceous vegetation means were: $7 \%$, forb cover $22 \%$ grass cover, $29 \%$ total cover and $17 \mathrm{~cm}$ grass height. None of these vegetative characteristics were different than random sites which implies that hens were not selecting for any of these vegetative characteristics (Table 2). Wallestad (1971) also noted that broods used upland sagebrush-grassland types, especially early in the summer. 


\section{Ml Macrothink}

Table 2. Comparisons of vegetation parameter means at sage-grouse brood and random sites, yearling and adults and brood and nest sites from Montana in 2003-2004

\begin{tabular}{|c|c|c|c|c|c|c|c|c|}
\hline & & \multicolumn{3}{|c|}{ Shrub Characteristics } & \multicolumn{4}{|c|}{ Herbaceous Characteristics } \\
\hline & $\mathrm{N}$ & $\begin{array}{l}\text { total } \\
\text { cover }\end{array}$ & $\begin{array}{c}\text { total } \\
\text { density }\end{array}$ & $\begin{array}{l}\text { shrub } \\
\text { height }\end{array}$ & $\begin{array}{l}\text { forb } \\
\text { cover }\end{array}$ & $\begin{array}{l}\text { grass } \\
\text { cover }\end{array}$ & $\begin{array}{l}\text { total } \\
\text { cover }\end{array}$ & $\begin{array}{l}\text { grass } \\
\text { height }\end{array}$ \\
\hline & & $(\%)$ & $\left(\operatorname{shrubs} / \mathrm{m}^{2}\right)$ & $(\mathrm{cm})$ & \multicolumn{3}{|c|}{--------(\%)---------- } & $(\mathrm{cm})$ \\
\hline Brood $^{1}$ & 48 & 14 & 1.2 & 34 & 7 & 22 & 29 & 17 \\
\hline Random & 73 & 14 & 1.1 & 34 & 8 & 21 & 34 & 18 \\
\hline Yearling & 11 & 12 & 1.2 & $31^{\mathrm{a}}$ & 6 & 22 & 28 & 17 \\
\hline Adult & 36 & 14 & 1.3 & $35^{\mathrm{b}}$ & 7 & 20 & 27 & 17 \\
\hline Brood & 48 & $14^{\mathrm{a}}$ & 1.2 & $34^{\mathrm{a}}$ & - & - & - & - \\
\hline Nest & 101 & $21^{\mathrm{b}}$ & 1.4 & $39^{\mathrm{b}}$ & - & - & - & - \\
\hline
\end{tabular}

${ }^{1}$ based on Roundup and Decker, MT.

${ }^{a}$ Numbers with different superscripts are different at $\mathrm{P} \leq 0.05$.

Martin (1970) observed that sagebrush cover for broods in Beaverhead County in southwestern Montana averaged $19 \%$, while Wallestad and Pyrah (1974) noted that broods used areas with $13 \%$ shrub cover. Connelly, Schroeder, Sands and Braun (2000) suggested that broods need 10-25\% sagebrush canopy cover, and shrub cover for brood sites in our study areas fall within this range. Connelly, Schroeder, Sands and Braun (2000) also suggested that broods need sagebrush height greater than $40 \mathrm{~cm}$. Sagebrush height in our three study areas did not meet this guideline, therefore, this guideline may not be applicable to our locations.

No differences in shrub characteristics between brood sites and random sites were detected. Klebenow (1969) observed that broods used less dense sagebrush habitat at 1.7 shrubs per $\mathrm{m}^{2}$ than in the overall sagebrush habitat type at 2.9 shrubs per $\mathrm{m}^{2}$ in Idaho. Holloran (1999) observed that broods were in areas of 2.5 shrubs per $\mathrm{m}^{2}$ in Wyoming. Martin (1965) noted that broods were in areas of 1.1 shrubs per $\mathrm{m}^{2}$ in southwestern Montana.

The only vegetative characteristic which was different between yearling and adult sage-grouse hens was the average shrub height. Adult hens appeared to select for taller $(\mathrm{P} \leq 0.05)$ Wyoming big sagebrush plants compared to yearling hens (35 vs $31 \mathrm{~cm}$ ), Table 2).

Canopy coverage values at brood sites for forbs, grasses, and all herbaceous vegetation ranged from 7\%, $22 \%$, and 29\%, respectively, and grass heights averaged $17 \mathrm{~cm}$. Connelly, Schroeder, Sands and Braun (2000) suggested that broods need a combined grass and forb cover that is greater than $15 \%$, although they noted that grass heights are variable depending on the grass species present. 


\section{Ml Macrothink}

Environmental Management and Sustainable Development

ISSN 2164-7682 2017, Vol. 6, No. 1

Brood locations had less $(\mathrm{P} \leq 0.05)$ shrub cover and shorter shrubs than nest locations (Table 2). Herbaceous vegetation measurements were not compared between brood and nest locations since they were taken at different times of the year.

Our results are consistent with Hagen, Connelly and Schroeder (2007), who found hens with broods selected areas with less sagebrush cover than nest sites. They further reported that during the brood rearing stages, sagebrush cover decreased from early to late periods.

\section{Conclusion and Management Implications}

Our study found that Wyoming big sagebrush vegetation types are vital for nesting and brood-rearing sage-grouse. Ninety-seven percent of nests and $92 \%$ of brood locations were in sagebrush vegetation. Sagebrush cover was the only parameter in central Montana that consistently met the suggested guidelines of Connelly (2000). Sagebrush heights were lower at Roundup and Malta than the suggested guideline. Therefore, the sagebrush cover guideline proposed by Connelly, Schroeder, Sands and Braun (2000) appears to be an appropriate indicator of nesting and brood-rearing habitat in Montana, but the sagebrush height guideline does not.

Although sage-grouse hens selected nest sites for taller and more productive shrubs, this did not influence nest success. Likewise, herbaceous vegetation did not influence nest selection or nest success. This would suggest that even though most livestock grazing guidelines are designed to leave more residual herbaceous cover and height to increase nest success, it may not decrease nest loss due to predation.

Sage-grouse hens generally select brood rearing areas with less sagebrush cover and more herbaceous cover than nest sites. This finding has prompted some land managers to reduce sagebrush cover in order to increase brood-rearing habitat. This practice ignores the mobility of the hen at that life stage, and the overlap of nesting and brood-rearing habitats in many populations. It also assumes that the brood-rearing habitat is a limiting factor to sage-grouse populations. We believe that sagebrush cover should not be reduced in the Wyoming big sagebrush vegetation type because it is important to sage-grouse in the nesting and wintering periods.

\section{Acknowledgement}

This project was partially funded by the August L. Hormay Memorial Scholarship, the Montana Agricultural Experiment Station and Montana Fish, Wildlife and Parks. We thank Mark Goetz for assisting with vegetation measurements in 2004. We also thank Brett Walker and Glenn Hockett for measuring and providing nest and brood vegetation data for Decker in 2003 and Brendan Moynahan for obtaining nest locations and nest site vegetation measurements for Malta in 2003.

\section{References}

Aldridge, C. L., \& Brigham, R. M. (2002) Sage-Grouse nesting and brood habitat use in southern Canada. Journal of Wildlife Management, 66, 433-444.

https://doi.org/10.2307/3803176 
Connelly, J. W., \& Braun, C. E. (1997). Long-term changes in sage-grouse Centrocercus urophasianus populations in western North America. Wildlife Biology, 3, 229-234.

Connelly, J. W., Reese, K. P., \& Schroeder, M. A. (2003). Monitoring of greater sage-grouse habitats and populations. University of Idaho, College of Natural Resources Experimental Station Bulletin 80, Moscow. 50pp.

Connelly, J. W., Schroeder, M. A., Sands, A. R., \& Braun, C. E. (2000). Guidelines to manage sage-grouse populations and their habitats. Wildlife Society Bulletin, 28, 967-985.

Crawford, J. A., Olson, R. A., West, N. E., Mosley, J. C., Schroeder, M. A., Whitson, T. D., Miller, R. F., Gregg, M. A., \& Boyd, C. S. (2004). Ecology and management of sage-grouse and sage-grouse habitat. Journal of Range Management, 57, 2-19.

https://doi.org/10.2307/4003949

Daubenmire, R. F. (1959). A canopy-coverage method of vegetation analysis. Northwest Science, 33, 43-64.

Doherty, K. E., Naugle, D. E., Tack, J. D., Walker, B. L., Graham, J. M., \& Beck, J. L. (2014). Linking conservation actions to demography: grass height explains variation in greater sage-grouse nest survival. Wildlife Biology, 20, 320-325. https://doi.org/10.2981/wlb.00004

Drut, M. S., Pyle, W. H., \& Crawford, J. A. (1994). Technical note: diets and food selection of sage grouse chicks in Oregon. Journal of Range Management, 47, 90-93.

https://doi.org/10.2307/4002848

Gregg, M. A. (1991). Use and selection of nesting habitat by sage-grouse in Oregon [thesis]. Oregon State University, Corvallis, USA.

Gurevitch, J., Scheiner, S. M., \& Fox, G. A. (2002). The ecology of plants. Sunderland, MA: Sinauer Association, Inc. 523 p.

Hagen, C. A, Connelly, J. W., \& Schroeder, M. A. (2007). A meta-analysis of greater sage-grouse Centrocercus urophasianus nesting and brood-rearing habitats. Wildlife Biology, 13(Suppl.1), 27-35.

Holloran, M. J. (1999). Sage grouse (Centrocercus urophasianus) seasonal habitat use near Casper, Wyoming [thesis]. University of Wyoming, Laramie.

Klebenow, D. A. (1969). Sage-grouse nesting and brood habitat in Idaho. Journal of Wildlife Management, 33, 649-662. https://doi.org/10.2307/3799390

Martin, N. S. (1965). Effects of chemical control of sagebrush on the occurrence of Sage-grouse in southwestern Montana [thesis]. Montana State University, Bozeman, Montana.

Martin, N. S. (1970). Sagebrush control related to habitat and sage-grouse occurrence. Journal of Wildlife Management, 34, 313-320. https://doi.org/10.2307/3799015

Montana Sage-grouse Work Group (MSGWG). (2002). Management plan and conservation 
strategies for sage-grouse in Montana - final draft plan. Montana Sage-grouse Work Group. $200 \mathrm{pp}$.

Moynahan, B. J. (2004). Landscape-scale factors affecting population dynamics of greater sage-grouse (Centrocercus urophasianus) in north-central Montana, 2001-2004 [dissertation]. University of Montana, Missoula, Montana.

National Oceanic and Atmospheric Administration (NOAA). (2003a) Annual climatological summary, Decker, Montana. Available at: http://cdo.ncdc.noaa.gov/ancsum/ACS. Accessed Mar. 16, 2005.

NOAA. (2003b) Annual climatological summary, Malta, Montana. Available at: http://cdo.ncdc.noaa.gov/ancsum/ACS. Accessed Mar. 16, 2005.

NOAA. (2004) Annual climatological summary, Roundup, Montana. Available at: http://cdo.ncdc.noaa.gov/ancsum/ACS. Accessed March 16, 2005.

Pyrah, D. B. (1972) Effects of chemical and mechanical sagebrush control on sage grouse. Montana Fish and Game Department, Job Completion Report W-105-R-6, Helena, USA.

Rowland, M. M. (2004) Effects of management practices on grassland birds: Greater Sage-grouse. Northern Prairie Wildlife Research Center, Jamestown, ND. 45 pp.

Schroeder, M. A., Hays, D. W., Livingston, M. F., Stream, L. E., Jacobson, J. E., \& Pierce, D. J. (2000). Changes in the distribution and abundance of Sage-grouse in Washington. Northwestern Naturalist, 81, 104-112. https://doi.org/10.2307/3536821

United States Department of Agriculture (USDA). (1981) Technical guide. Section II-E-8. USDA-SCS-MT. August 1981.

USDA. (2003). Soil survey of Musselshell County, Montana. NRCS office, Bozeman, Montana.

USDA Natural Resource Conservation Service (NRCS). (2004). Soil data mart. Available at: http://soildatamart.nrcs.usda.gov. Accessed 31 March 2005.

Wakkinen, W. L. (1990). Nest site characteristics and spring-summer movements of migratory sage-grouse in southeastern Idaho [thesis]. University of Idaho, Moscow. 57 pp.

Wallestad, R. O. (1971). Summer movements and habitat use by sage grouse broods in central Montana. Journal of Wildlife Management, 35, 129-136.

https://doi.org/10.2307/3799881

Wallestad, R. O. (1975). Life history and habitat requirements of sage-grouse in central Montana. Montana Fish and Game Department, Technical Bulletin, Helena, USA.

Wallestad, R. O., \& Pyrah, D. B. (1974). Movement and nesting of sage-grouse hens in central Montana. Journal of Wildlife Management, 38, 634-637.

https://doi.org/10.2307/3800030

Wambolt, C. L., Creamer, W. H., \& Rossi, R. J. (1994) Predicting big sagebrush winter forage 


\section{Macrothink}

by subspecies and browse form class. Journal of Range Management, 47, 231-234. https://doi.org/10.2307/4003022

Wambolt, C. L., Harp, A. J., Welch, B. L., Shaw, N., Connelly, J. W., Reese, K. P., ...Tanaka, J. A. (2002). Conservation of Greater Sage-Grouse on Public Lands in the Western U.S.: Implications of Recovery and Management Policies. Policy Analysis Center for Western Public Lands Policy Paper SG-02-02. Caldwell, Idaho.

Wambolt, C. L., Frisina, M. R., Knapp, S. J., \& Frisina, R. M. (2006). Effict of method, site and taxon on line intercept estimates of sagebrush cover. Wildlife Society Bulletin, 34(2), 440-445. https://doi.org/10.2193/0091-7648(2006)34[440:EOMSAT]2.0.CO;2

Western Regional Climate Center (WRCC). (2004). Malta 35S, Montana climate summary. Available at: http://www.wrcc.dri.edu/summary/climsmmt.html. Accessed March, 18, 2005.

\section{Copyright Disclaimer}

Copyright for this article is retained by the author(s), with first publication rights granted to the journal.

This is an open-access article distributed under the terms and conditions of the Creative Commons Attribution license (http://creativecommons.org/licenses/by/3.0/). 